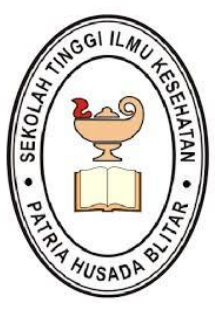

JNK

JURNAL NERS DAN KEBIDANAN

(JOURNALOFNERS AND MIDWIFERY)

http://jnk.phb.ac.id/index.php/jnk

\title{
The Effectiveness of Virgin Coconut Oil on the Decrease of Blood Glucose Levels on Gestational Diabetes Mellitus
}

Noer Saudah ${ }^{1}$, Indah Lestari ${ }^{2}$, Catur Prasastia Dewi Lukita ${ }^{3}$, Sahrir Sillehu ${ }^{4}$, Joel Rey U. Acob ${ }^{5}$

1,2,3 Nursing Department, Institute of Health Science Bina Sehat Mojokerto, Indonesia

${ }^{4}$ Nursing Department, Institute of Health science Maluku Husada Seram Maluku, Indonesia

${ }^{5}$ Faculty of Nursing, Visayas State University Philiphine, Philiphine

\begin{tabular}{|c|c|}
\hline Article Information & Abstract \\
\hline $\begin{array}{l}\text { History Article: } \\
\text { Received, 21/08/2021 } \\
\text { Accepted, 02/12/2021 } \\
\text { Published, 15/12/2021 } \\
\text { Keywords: } \\
\text { Virgin Coconut Oil, Blood Glucose } \\
\text { Level, Gestational Diabetes Mellitus, } \\
\text { Hypoglyicemic }\end{array}$ & $\begin{array}{l}\text { Gestational Diabetes Mellitus (GDM) was medical complication that occurs } \\
\text { during pregnancy and caused preterm labor. Efforts reduce blood glucose } \\
\text { levels and improve pancreatic performance must be safe both for mother and } \\
\text { fetus. The research aimed to prove VCO can reduce blood glucose levels in } \\
\text { GDM. The research design was quasi-experimental with one group pre-test } \\
\text { and post-test. The research started on March to September } 2020 \text {. The popu- } \\
\text { lation was pregnant mother with GDM from two hospitals in Mojokerto East } \\
\text { Java. The sample was } 46 \text { respondents with purposive sampling. The treat- } \\
\text { ment given was VCO at a dose of } 5 \mathrm{ml}, 6 \text { times a day and lowcarb diet. The } \\
\text { instrument used to measure the fasting blood glucose was glucose stick. } \\
\text { The data was analyzed with paired t-test. The result showed blood glucose } \\
\text { levels before intervention average of } 155.19 \text { mg/dL and after } 153.50 \text { mg/dL. } \\
\text { The t-test value } 14.442 \text { and p value } 0.000 \text { which meant that VCO and low carb } \\
\text { diet was more effective in reducing blood glucose levels on GDM. The ad- } \\
\text { ministration of VCO with a low carb diet is an effort to restrict glucose intake } \\
\text { in the body without hypoglycemia. It is safe to use for both mother and fetus } \\
\text { as an alternative non-pharmacological therapy on GDM and prevent preterm } \\
\text { labor. }\end{array}$ \\
\hline
\end{tabular}

(C) 2021 Journal of Ners and Midwifery

\footnotetext{
Correspondence Address:

Institute of Health Science Bina Sehat Mojokerto - East Java, Indonesia

P-ISSN : 2355-052X

Email: noersaudah15@gmail.com

E-ISSN : $2548-3811$
}

DOI: 10.26699/jnk.v8i3.ART.p271-275

This is an Open Access article under the CC BY-SA license (http://creativecommons.org/licenses/by-sa/4.0/) 


\section{INTRODUCTION}

Diabetes mellitus in pregnancy (Gestational Diabetes Mellitus abbreviated as GDM) is a normal pregnancy accompanied by an increase in insulin resistance (pregnant women fail to maintain euglycemia). The risk factors for GDM are a family history of DM, obesity, and glycosuria. This GDM increases the incidence of preeclampsia so that babies are born preterm and neonatal morbidity, for example hypoglycemia, jaundice, polycythemia, and macrosomia (Setyorogo et.al., 2013). This happens because gestation diabetes mellitus secretes greater insulin and stimulates the growth of the baby and macrosomia. The frequency of about $3-5 \%$ and the risk of the mothers increasing to become DM in the future (Setyorogo et.al., 2013).

In Indonesia, the prevalence of GDM is around 1.9-3.6\% and about 40-60 women who have experienced GDM in postpartum follow-up will develop Diabetes Mellitus or impaired glucose tolerance. Incident of GDM increased in pregnant women with risk factors such as increasing body weight during pregnancy $>0.5 \mathrm{~kg} /$ week, age more than 25 years, history of family DM, GDM history, and ethnicity (Soelistijo et.al., 2015). Risk factors for women with GDM are women diagnosed with gestational diabetes with $17 \%-63 \%$ of type 2 diabetes within 5-16 years in ethnic groups different (Daundasekara et al., 2017).

Anti-diabetic medicine is drugs work to help enter glucose into cells, so that glucose levels in the blood decreases (Setyorogo et.al., 2013). But this mechanism does not repair cell damage in producing insulin and does not help receptors in binding to insulin. The alternative that is conserved in this study is Virgin Coconut Oil (VCO). VCO is a type of fat that can be consumed by pregnant women with diabetes mellitus which have no impact to fetal growth and development (Purnamasari et.al., 2013). VCO contains saturated fat from coconuts that can be consumed by people with diabetes mellitus. VCO fat will regulate blood glucose levels and improve the work system of the pancreas that supplies insulin in the body. The body will gain energy due to the pancreatic gland being able to convert glucose to energy. In a normal body, insulin functions to convert glucose into energy. VCO contains high chain saturated fatty acids (medium chain fatty acids or MCFA), especially lauric acid with a content of between $43-53 \%$ of total fatty acids. The presence of MCFA has a dual role, which can induce insulin secretion and improve insulin function. In contrast to other fats, MCFA in VCO does not experience deposition during circulation in the bloodstream, but directly to the liver which will soon be converted into 100\% energy (Kabisch et al., 2018).

Giving VCO with a low carb diet is an attempt to restrict glucose levels in the body. The role of energy sources due to glucose (low carb) restriction will be replaced by VCO so that pregnant women with GDM are fulfilled by their caloric needs. VCO is proven to be an antidiabetic alternative (Iranloye et.al., 2013). The intake of coconut oil will soon be converted into energy and not stored as body fat so that it has a very positive effect on weight loss for people with diabetes mellitus (Kabisch et al., 2018).

Intake of coconut oil is also proven to increase the absorption of minerals $\mathrm{Ca}$ and $\mathrm{Mg}$ if there are deficiencies of both minerals in the body, which is a condition that is often encountered in people with diabetes mellitus. Calcium supplementation can increase insulin sensitivity in certain populations, while magnesium supplementation can increase insulin secretion and or increase insulin sensitivity and peripheral glucose intake. In addition, VCO supplementation can also improve antioxidant status. The aim of this study is to prove that VCO and low carb diets can reduce blood glucose levels in GDM. So that it can prevent babies born preterm and can reduce neonatal mortality.

\section{METHOD}

Research design used quasi experiments with one group pre-test and post-test design. Population were pregnant with GDM from two hospitals in Mojokerto East Java. There were 46 respondents involved in this research. The sampling technique used purposive sampling. The treatment given was VCO at a dose of $5 \mathrm{ml}, 6$ times a day and lowcarb diet. Variable research were VCO and blood glucose. The instrument used to measure the fasting blood glucose was glucose stick before and after treatment on day $21^{\text {th }}$. Analysis of data used paired t-test with a 0.05 level of confidence (Setiadi, 2013). The willingness of respondents was stated with informed consent and the research had gone through the ethical test from College of Health Science Maluku Husada. The time of research is starting from March to September 2020. 


\section{RESULT}

\section{The Characteristic of Responden}

Table 1 The characteristic of Respondent Based on Age, Parity and Age Gestation

\begin{tabular}{llcc}
\hline \multirow{2}{*}{ Characteristic } & \multirow{2}{*}{ Indicator } & \multicolumn{2}{c}{ Treatment } \\
\cline { 3 - 4 } Age & \multicolumn{1}{c}{$\boldsymbol{\Sigma}$} & $\boldsymbol{\%}$ \\
\hline & 20-25 years & 8 & 17.4 \\
& 26-30 years & 6 & 13 \\
& 31-35 years & 14 & 30.4 \\
& $>$ 35 years & 18 & 39.2 \\
\hline \multirow{2}{*}{ Parity } & 1th & 28 & 60.9 \\
& 2th & 12 & 26.1 \\
& 3th & 6 & 13 \\
\hline \multirow{2}{*}{ Age gestation } & 28-31 weeks & 26 & 56.5 \\
& 32-35 weeks & 20 & 43.5 \\
& 36-40 weeks & 0 & 0 \\
\hline Total & & $\mathbf{4 6}$ & $\mathbf{1 0 0}$ \\
\hline
\end{tabular}

Resource : Primary data, 2020
Based on Table 1, it showed, there were 18 respondents $(39.2 \%)$ age $>35$ years. Statistic data shows there were 28 respondents first pregnancy $(60.9 \%)$. The statistical data shows that there were 26 respondents $(56.6 \%)$ whose gestational age between 28 until 31 weeks.

Based on Table 2 mean fasting blood glucose levels before treatment VCO and low carb diets is $155.19 \mathrm{mg} / \mathrm{dL}$ and mean fasting blood glucose levels after treatment is $151.50 \mathrm{mg} / \mathrm{dL}$. It is mean blood glucose levels after treatment lower than before treatment.

Based on data analysis in Table 3 used paired $\mathrm{t}$-test with value correlation $\mathrm{p}=0.000$. This means the effect of VCO and low carb diets on decrease fasting blood glucose levels in gestational diabetes mellitus. Paired t-test shows value $\mathrm{p}=0.000(\leq 0.05)$ this means a significant difference between fasting blood glucose levels before and after given VCO and low carb diets. Combination of VCO and low carb diets could decrease blood glucose in pregnant women with diabetes mellitus.

Table 2 Results of Descriptive Analysis of Blood Glucose Levels Before and After Given VCO and Lowcarb Diets

\begin{tabular}{llc}
\hline Variable & Mean & Standard Deviation \\
\hline Blood glucose before treatment & 155.19 & 11.365 \\
Blood glucose after treatment & 151.50 & 11.788 \\
\hline
\end{tabular}

Table 3 Result Paired t-test

\begin{tabular}{lcccc}
\hline \multirow{2}{*}{ Variable } & \multicolumn{2}{c}{ Paired samples correlation } & \multicolumn{2}{c}{ Paired sampel t- test } \\
\cline { 2 - 5 } & correlation & significant & t-tes & Sig. (2-tailed) \\
\hline Blood glucose before and after & 0.989 & 0.000 & 14.224 & 0.000 \\
\hline
\end{tabular}

\section{DISCUSSION}

Pregnant women over the age of 35 years have a higher risk of developing gestational diabetes due to the influence of pregnancy hormones and risk for preterm labor (Saudah et al., 2015). The firstpregnancy at the age of $>35$ years are at risk of pregnancy disorders example preeclampsi, gestational diabetes or other disorders (Joeliantina et al., 2019). Statistic data shows there were 28 respondents first pregnancy $(60.9 \%)$. This shows that the first pregnancy at non-productive age $>35$ years is very risky to the safety of the mother and fetus. It is very important to increase the knowledge and understanding women reproductive and families about gestational age before 35 years. This can prevent the high rate of pregnancy with diabetes mellitus (Tebbani et.al., 2017). There were 26 respondents $(56.6 \%)$ whose gestational age between 28 until 31 weeks. Gestational diabetes mellitus can occur at any gestational age, but usually occurs between 24 and 30 weeks of gestation (Purnamasari et.al., 2013; Soliman et.al., 2018). Examinations 
that must be done to determine the presence of gestational diabetes in pregnant women after fasting 8-14 hours and plasma blood sugar after 2 hours of fasting.

Diabetes Mellitus in pregnancy causes complications in pregnancy and will prevent fetal wellbeing which can lead to preterm labor. Besides, it can cause metabolic disorders in the mother's body. Anti-diabetic drugs for a longer period of time may have undesirable effects on both pregnant women and the fetus. In addition, drug dependence will have an impact on the economy. The solution to this problem is in the form of natural anti-diabetic foods with the lowest pain effects and low costs are the most desirable. VCO, contains medium chain saturated fatty acids (MCFA), especially lauric acid with a content of between $43-53 \%$ of total fatty acids. Lifestyle intervention reduced the incidence by 58 percent ( 95 percent confidence interval, 48 to 66 percent) and metformin by 31 percent (95 percent confidence interval, 17 to 43 percent), as compared with placebo; the lifestyle intervention was more effective than metformin. To prevent one case of diabetes during a period of three years, 6 from 9 persons would have to receive metformin. Person changes and treatment with metformin in persons at high risk The intervention lifestyle was more effective than metformin (Iranloye et.al., 2013).

In this research gestational diabetes mellitus were given VCO and low carb. Giving VCO with a low carb diet is an attempt to restrict glucose levels in the body. The role of energy sources due to glucose (low carb) restriction will be replaced by VCO so that gestational diabetes mellitus are fulfilled by their caloric needs. VCO is proven to be an antidiabetic alternative (Iranloye et.al., 2013). Beside that VCO is an antioxidant can increase sensitivity to insulin or vice versa can also reduce insulin resistance and repair damage to pancreatic beta cells with the process of reactive oxygen (ROS) in diabetic patients.

Gestational diabetes has various impacts on the mother and fetus, including increasing the risk of the mother experiencing preterm labor. In addition, large gestational age and macrosomia are often found in infants born to mothers with gestational diabetes. This can be prevented by carrying out various interventions before and during pregnancy. The indicator of the success of prevention is the results of examination of fasting blood glucose levels $<91 \mathrm{mg} / \mathrm{dL}$ and blood sugar after meals <200 $\mathrm{mg} / \mathrm{dL}$ (WHO, 2013).

VCO is an antioxidant can increase sensitivity to insulin or vice versa can also reduce insulin resistance and repair damage to pancreatic beta cells with the process of reactive oxygen (ROS) in diabetic patients (Kabisch et al., 2018; Stocker et al., 2019). Low carb diet is an attempt to restrict glucose levels in the body. The role of energy sources due to glucose (low carb) restriction will be replaced by VCO so that pregnant women with diabetes mellitus are fulfilled by their caloric needs (ADA, 2015).

\section{CONCLUSION}

VCO and a low carb diet is way more effective in reducing blood glucose in Gestational Diabetes Mellitus. Low carb diet can restrict glucose intake in the body without hypoglycemia because the role of energy sources were replaced by VCO. It is safe to use for both mother and fetus as an alternative non-pharmacological therapy on GDM and prevent preterm labor.

\section{SUGGESTION}

Pregnant women who are at risk of diabetes mellitus should maintain a good lifestyle including reducing high-carbohydrate foods so that there is no increase in blood sugar during pregnancy.

\section{REFERENCES}

American Diabetes Association (2015) '12. Management of diabetes in pregnancy', Diabetes Care, 38(January), pp. S77-S79. doi: 10.2337/dc15-S015.

Daundasekara, S. S. et al. (2017) 'Validation of the intuitive Eating Scale for pregnant women', Appetite, 112, pp. 201-209. doi: 10.1016/j.appet.2017.02.001.

Iranloye, B., Oludare, G. and Olubiyi, M. (2013) 'Antidiabetic and antioxidant effects of virgin coconut oil in alloxan induced diabetic male Sprague Dawley rats', Journal of Diabetes Mellitus, 03(04), pp. 221226. doi: 10.4236/jdm.2013.34034.

Ji, W.W., Yu, D.A., Fan, M., You, M., Lu, Y., Li, E.B., Xie, N. and Yan, S. S. (2017) 'Effects of GW002, a novel recombinant human glucagon-like peptide-1 (GLP1) analog fusion protein, on $\mathrm{CHO}$ recombinant cells and BKS-db mice.', Acta diabetologica, 54(7), pp. 685-693.

Joeliantina, A. et al. (2019) 'Family support for diabetes self-care behavior in $\mathrm{t} 2 \mathrm{dm}$ patients who use herbs as a complementary treatment', Medico-Legal Update, 19(1), pp. 238-243. doi: 10.5958/09741283.2019.00048.3. 
Kabisch, S. et al. (2018) 'Liver fat scores moderately reflect interventional changes in liver fat content by a low-fat diet but not by a low-carb diet', Nutrients, 10(2). doi: 10.3390/nu10020157.

Purnamasari, D., Waspadji, S., Adam, J. M., Rudijanto, A., \& Tahapary, D. (2013) 'Indonesian Clinical Practice Guidelines for Diabetes in Pregnancy', Journal of the ASEAN Federation of Endocrine Societies, 28(1), pp. 9-9.

Saudah, N. et al. (2015) 'Model of Independency Mother in Caring for Preterm Infant based on Experiential Learning Care (ELC)', International Journal of Evaluation and Research in Education (IJERE), 4(4), p. 200. doi: 10.11591/ijere.v4i4.4512.

Setiadi (2013) Konsep dan Praktik Penulisan Riset Keperawatan. 2nd edn. Jogjakarta: Graha Ilmu.

Setyorogo, S. and Trisnawati, S. . (2013) 'Faktor Resiko Kejadian Diabetes Melitus Tipe II Di Puskesmas Kecamatan Cengkareng Jakarta Barat Tahun 2012', Jurnal Ilmiah Kesehatan, 5(1), pp. 6-11.

Soelistijo, S.A., Novida, H., Rudijanto, A., Soewondo, P.,
Suastika, K., Manaf, A., Sanusi, H., Lindarto, D., Shahab, A., Pramono, B. and Langi, Y. (2015) 'Konsensus pengelolaan dan pencegahan diabetes melitus tipe 2 di Indonesia', Jakarta: $P B$ Perkeni, pp. 1-93.

Soliman, A.M., Lin, T.S., Ghafar, N.A. and Das, S. (2018) 'Virgin coconut oil and diabetic wound healing: histopathological and biochemical analysis.', Eur. $j$. anat, pp. 135-144.

Stocker, R.K., Bally, L., Nuoffer, J.M. and Stanga, Z. (2019) 'Ketogenic diet and its evidence-based therapeutic implementation in endocrine diseases', Praxis, 108(8), p. pp.541-553.

Tebbani, F., Oulamara, H. and Agli, A. (2017) 'Early weight gain during pregnancy: Which women are the most affected?', International Journal of Medical Science and Public Health, p. 1. doi: 10.5455/ ijmsph.2017.0208623012017.

WHO (2013) Diagnostic and Classification of Hyperglicemia First Detection in Pregnancy, WHO. 